\title{
Corporate Responsibility in Scarcity Economy. The Olivetti Case
}

\author{
Elisa Arrigo*
}

\begin{abstract}
Corporate responsibility tends to take different forms in relation to the different competitive conditions in which a company operates. The purpose of the paper is to analyse corporate responsibility in scarcity economy, with demand largely exceeding supply. In this situation, corporate responsibility, in the main, seeks profitability as the primary goal.

The Olivetti case is analyzed to show how the conditions of company wellbeing simply reflect corporate social responsibility, where company growth is directly associated with the development of relations within the local environment as well as social relations.
\end{abstract}

Keywords: Corporate Responsibility; Corporate Social Responsibility; Scarcity Economy Competition; The Olivetti Case

\section{Corporate Responsibility in Business-Environment Relations}

The many notions of 'firm' put forward in management doctrine highlight the growing importance attributed to understanding relations with the environment on one side, and recognition of the social implications of corporate activities on the other. Corporate responsibility ${ }^{1}$ is one of the elements that enable us to analyse the interaction between a firm and its environment, where the environment is the sum of entities, whether systemic ${ }^{2}$ or not, that surround the firm, in the context of which the latter operates. Analysis of the relationship between business and environment has acquired greater importance in the academic field because the environment itself has become significantly more complex. The systemic approach is a theoretical conception that successfully grasps the evolutions in corporate management and its interaction with its environment. The firm is a system within other super-systems, which reconciles social, political and ethical aspects that actually emphasise its economic nature ${ }^{3}$, and its role is, on one hand, to identify and qualify the environmental context, defined by a series of political, legislative, social, cultural and economic conditions that characterise the many constraints-

* Lecturer in Management, University of Milan-Bicocca (elisa.arrigo@unimib.it) 
opportunities ${ }^{4}$ within which it operates and, on the other, to identify the impact these conditions may have on its evolution.

In his scientific production, Gino Zappa already assigned a pre-eminent role to the concept of the environment and the firm's dependence on it. In his Le produzion nell'economia delle imprese $e^{5}$, he reproached the students of his day for having presupposed an environmental staticness that was in fact fictitious, and he claimed that "not a few deficiencies of the corporate doctrines must be attributed to the deliberate abstraction of firms' development from the considerable influence exerted on them by the environment in which economic management is exercised. Corporate development laws can never be investigated by considering the firms separately, stripped of the thick weave of relations that tie them to the sensitive and moral world which, by enveloping them, stimulates and directs them at given times to various different ends'. Students of corporate management and businessmen therefore have to monitor the environmental characteristics carefully and continuously, and the firm has to adopt dynamic management systems that reflect environmental changes.

In the same period, while he attenuated the firm's dependence on its environment contained in Zappa's formulation, Pietro Onida maintained that 'this mutability of the environment is reflected in the firm's entire organisation' ${ }^{6}$ and that 'as a social institute, the firm must help to increase man's well-being and personality and foster the achievement of the goals of associated human life, which are primarily ethical ${ }^{7}$ highlighting the social repercussions of a business's activities in the environment.

A decade later, Pasquale Saraceno ${ }^{8}$ made an important contribution regarding the business-environment relationship, recognising that it was possible for the firm to modify the external context with a series of actions designed to make the environmental situation compatible with the business activities.

Carlo Masini asserted the 'principle of man's dominion over things and relations', maintaining that the individual and the firm were capable of envisaging, interpreting and dominating the changing environment. The author also regarded the business as an economic-social community that forges relations with the external environment, 'with familiar firms that provide work and contribute capital, with suppliers or with clients, with public authorities..., ${ }^{10}$, and contributes to the achievement of the common good of the country. In his book Lavoro e Risparmio, Masini considered the environment, inside which it was possible to identify numerous subjects and links, on the basis of the relations and relationships existing between the firm and other institutes.

It therefore appears evident that as environmental complexity has increased, evolving from relatively stable, known competitive contexts to others that are much more dynamic and unpredictable, the business-environment relationship has changed, becoming much more ramified.

Corporate responsibility is part of the relationship between the firm and the environment because the firm answers for the actions that it performs directly or indirectly in the environment, and for their consequences, and it is structural in character; in fact this concept pervades the entire organisation, and is innate in the very notion of business, its role in society and its rights-duties in relation to the internal and external environment. Corporate responsibility has repercussions both on operating management and on internal cohesion processes and is therefore expressed through a number of actions and behaviour that are directed both inside 
the firm, with policies to develop the potential of human capital and towards the outside world, through actions designed to acquire, maintain and increase consensus with consumers, suppliers, local authorities, investors and all other eternal stakeholders ${ }^{11}$.

The term social, which is often associated with corporate responsibility may, in that sense, be considered redundant because we expect a firm to answer for its own actions to society first of all; but it is also confusing, because it calls to mind an idea of welfarism, in other words, of activities performed in order to materially or morally help someone, which is not in fact the firm's function.

\section{The Evolution of Corporate Social Responsibility in Managerial Studies}

Executives and scholars began to show an interest in the ethical aspects ${ }^{12}$ of management and in corporate social responsibility in the 1930s and 1940s, but it was only in the 1950s that investigations were stepped up. The first important contribution came from Bowen ${ }^{13}$ in 1953, who gave a definition of social responsibility referred to the businessman. This contribution was significant because, although it focused on the responsibility of the managers rather than on that of the firm as a whole, it incorporates economic and social aspects of a business, recognising the latter's capacity to impact the social wellbeing of a determined community.

In the following decade ${ }^{14}, 1960-1970$, the international academic debate about corporate social responsibility took shape and outlined two schools of thought: one led by the economist and Nobel Prize winner Milton Friedman ${ }^{15}$, an advocate of the maximisation of profit as the only duty of the manager and the firm, and the other led by Davis ${ }^{16}$, Frederick ${ }^{17}$ and McGuire ${ }^{18}$, which attributed to the business vaster responsibilities than those purely economic or required by law, but did not indicate explicitly what they were. In his 'iron law of responsibility' Davis associated the firm's power with its responsibilities, because the strategies implemented by businessmen directly influence the firm, and he maintained that the firm would lose the power it had won if it did not take on its responsibilities.

In the period 1970-1980 definitions of this subject proliferated, but scholars did not reach a unanimous consensus, preferring to focus on the concepts of corporate social responsiveness and corporate social performance. In other words, they analysed the strategies that the firm could adopt to respond to the needs of society and thus to increase the harmony of the business-environment relationship, as well as the methodologies to measure corporate performance ex post, paying particular attention to managerial instruments.

Various aspects of the concept of corporate social responsibility were studied: Johnson ${ }^{19}$, for example, studied Freeman's theory of the stakeholder, and stated that ' $a$ socially responsible firm is one in which the managerial staff takes a multiplicity of interests into account'; Manne and Wallich ${ }^{20}$ underlined the fact that the firm's social activity must be voluntary. Davis ${ }^{21}$ on the other hand analysed the reasons for and against the assumption of social responsibility. Sethi ${ }^{22}$ identified three levels of corporate behaviour in reply to social demands: social obligations (of a proscriptive nature, only referred to respect of market and legal constraints), social responsibility (of a prescriptive nature, indicating respect of the main social values) and social responsiveness (relating to the firm's role in society and its 
anticipatory and preventive behaviour). Epstein $^{23}$ gave a new interpretation of corporate social responsibility that focused on results rather than on the values or manner of the firm response, and Carroll ${ }^{24}$, trying to overcome the confusion in the definition, identified four types of responsibility set out in hierarchical order: economic responsibilities, linked to the production of goods and services that could satisfy the requests of demand, sold at a price able to generate profit; legal responsibilities, regarding observance of current legislation; and ethical and philanthropic responsibilities, which presuppose respect of the rules not absorbed into law, and the performance of beneficial activities that society expects a firm to perform. To express the various levels of importance, the author positioned the four types of responsibility in a pyramid with economic responsibilities at its base, to underline the predominance of the economic function over the others, while philanthropic responsibility is positioned at the top, reflecting the purely discretionary activities undertaken in favour of the community.

There were two interesting contributions in the decade 1980-1990: Drucker ${ }^{25}$ proposed a new perspective to the issue, stating that the assumption of responsibility may be seen as a profitable economic opportunity and not only as a sum of additional costs, thus identifying the existence of a positive correlation between social responsibility and business possibilities. Frederick ${ }^{26}$ recognised the existence of three concepts that describe the relationship between business and environment: corporate social responsibility, corporate social responsiveness and corporate social rectitude, the latter expressing the firm's moral correctness when taking decisions and formulating strategies.

In brief, it seems evident that, in the United States, corporate social responsibility tends primarily to analyse relations between business and the external publics and, in particular, relations between business and clients/consumers. In Europe, on the other hand, corporate social responsibility primarily addresses the internal public, i.e. protecting employees. In France, for example, Marques ${ }^{27}$ distinguished between social responsibility, typical of the firm-worker relationship, and corporate responsibility that describes the relationship between the firm and the external environment. In Italy, the question has been debated by several authors in the past, and picked up again more vehemently in the last decade because current corporate competitive dynamics have made it necessary to forge new trusting relationships inside business and between the latter and the environment in which it operates ${ }^{28}$.

\section{Corporate Responsibility and Corporate Social Responsibility}

It now appears clear that corporate social responsibility does not only refer to philanthropy, donations, cause-related marketing and sponsorship, but is a much vaster, more complex concept. The corporate development takes place within numerous constraints, more or less significant depending on the influences inside and outside the firm. Above all, the need to guarantee a good balance between the aspirations of the various groups of individuals, involved in the operation of the firm system, generates a series of limitations in the choice of its business goals and strategies $^{29}$. It is innate to the concept of a business to take on economic and legal responsibilities, i.e. to answer for the production of goods and services, fostering the social and economic development of its target environment and also creating a profit that can guarantee the continuity of its activities in the long term in respect of 
the law. Although the State is responsible for promoting the wellbeing of society, guaranteeing the delivery of basic public services, the necessary infrastructures and, in general, management of the public system and the community, a firm is responsible for producing and distributing goods and services in response to the needs of the individual. A firm may be defined as 'that economic organisation which, by using a differentiated sum of resources, purchases and produces goods or services, to be traded with external entities in order to create income, 30 and 'economic activity consists in the production and consumption of economic assets that can meet the needs of the individual but are deficient in relation to the demands expressed by individuals ${ }^{31}$. The legal constraints obviously should not be undervalued, because every internal or external corporate initiative must be economically and legally feasible. The firm will be all the more responsible provided it is able to survive, generating income and economic and social growth, meeting the needs of its customers, guaranteeing financial revenues to investors, giving safe jobs to its employees and fostering social development in the competition space in which it operates. It must achieve a profit in order to survive, and its growth depends on its ability to meet the economic and social expectations of its stakeholders; in fact, a climate of conflict between a firm and the environment could have negative consequences on its ability to create income and therefore on the firm existence.

Following great socio-economic change, what social interlocutors expect from firms has also changed. Historically, the first period in which the social consequences of entrepreneurial activities emerged significantly in Italy, and in Europe as a whole, was the industrial revolution, which brought numerous sociocultural changes. Initially only the most enlightened entrepreneurs voluntarily took action in favour of their workers, but subsequently, even as a result of union action, this was formalised into legal obligations to protect them. Businessmen tried to offset the damage caused by the extensive migration of the population to the town and to address the economic problems of workers' families. The migratory flows from the countryside to the town had huge social and cultural consequences. Working life was extremely hard and subject to all sorts of controls: the scientific organisation of labour certainly improved the productivity and efficiency of firms, but it subjected the workforce to hard shifts and de-qualified their skills: from expert craftsmen, workers became an 'accessory' to the machine. So the first voluntary action was transformed into formalised relations between firms and employees following the creation of forms of collective representation and trades unions for workers.

In a market where products are scarce $e^{32}$, the situation typical of an artisan set-up, which continues until the spread and later the success of mass production, competition takes place in a local space that is limited on one side by the supply market and on the other by the outlet market, and is measured by the ability to generate economies of scale by optimising the use of manufacturing factors, capital and labour that can be found in the immediate proximity of the plant. The production and consumption of assets takes place in this territory, which is very clear and circumscribed; the local community is the firm's only benchmark environment. It is in this local community that the corporate responsibility is judged: the firm produces goods that meet the primary needs, improve the living conditions of the social interlocutors and the latter, in exchange, do not obstruct the corporate development in any way, nor does it impose respect of rules or values, 
maintaining a very permissive attitude ${ }^{33}$. In the corporate activities, the manufacturing function plays its primary role in relation to the presence on the market of a quantity of products that is insufficient to meet consumers' needs. What is more, the stability of purchasing behaviour and consumption of demand and the presence of limited competition simplify the programming of manufacturing activities from the firm perspective. As a result, this stresses a firm's economic responsibility within the four type of corporate social responsibility (i.e. economic, legal, ethical and philanthropic), in other words the commitment to make available on the market a functioning product that meets stakeholders' needs. Satisfying consumers' elementary needs by manufacturing goods brings the firm's economic function into line with its social function in a given competitive situation.

The gradual increase in the capacity of manufacturing plants improves both businesses' ability to respond quantitatively to consumers' requests, and the living conditions of the population. A new competitive context emerges, with an unstable balance between demand and supply, and a higher number of competitors. In these conditions, the firm focuses primarily on the product, which is differentiated either through the price lever or through product's intangible elements that sustain the tangible ones. Commercial and marketing activities are generated and developed to stimulate purchases of products from a particular firm. In this situation the parties directly or indirectly involved in a corporate activities start to develop greater concern to environmental and social issues, which were not considered previously, thus exerting pressure on corporate activities to force the firm to operate in respect of precise rules. The traditional correspondence between factory and local community, and the relationship of control and of collaboration that exists between the businessman and his fellow citizens diminishes because the competitive space starts to expand, without precisely definable boundaries.

As the situation evolves from one of 'dynamic balance between demand and supply' to one of 'over-supply', a new social demand ${ }^{34}$ is generated; it no longer generically expects goods or services to perform their primary function thus satisfying its elementary needs, but expects and demands a different approach to corporate operations, which focuses attention on the quality of the goods manufactured and assesses the costs met by the firm (or negative externalities ${ }^{35}$ ) arising from the manufacturing and consumption of said goods.

In a context of 'over-supply', the benchmark environment is no longer locally defined as it is in 'scarcity economy', but globally indefinite; the corporate system often adopts a network structure in response to environmental complexity, and operates on several markets through forms of de-localisation. In this situation, the firm's success depends on its ability to efficiently and effectively coordinate the system of corporate intangible assets, which can be defined as the managerial capabilities regarding the sum of knowledge and the channels that make it possible to acquire information vital for the firm, and are linked to the corporate culture, the information system and to brand equity ${ }^{36}$. To optimise this management, it is necessary to interact continually with the environment. In a competitive context of 'scarcity economy' the firm will adopt a push policy in relation to the market, producing standardised goods that it distributes by activating one-way physical and information flows, from the firm to the environment. In a context of 'over-supply', on the other hand, in order to perform its activities the firm must strategically manage two-way information flows, from the firm to the environment and from the 
environment to the firm. In 'scarcity economy', the legitimization of the firm is founded essentially on the manufacturing of goods, the generation of profit and of wellbeing for a community that is identified and well-known locally; but in the case of a global firm not linked to a specific territory or a particular social group, this legitimization must be acquired with numerous stakeholders. As a result it becomes necessary to express the corporate responsibility by communicating social commitment through the adoption of a sum of tools such as a sustainability report or ethical code. Without reducing the importance of the economic function or of economic responsibility over other corporate functions, the assumption of ethical and philanthropic responsibilities is stressed because it can represent a new source of competitive advantage for firms.

The firm no longer provides only the elementary functions of manufacturing and trade to meet the basic needs of demand and to create jobs for the workforce, but is considered an institution with precise social responsibilities in relation to the various communities in which it operates. It is important to build up stable relations with the market, with the community and with suppliers because the success of the firm will depend on the strength of these ties. What is more, to tackle the constraints created by the new social and environmental needs and to guarantee that the conditions of economic viability and durability are met, the firm must absorb these social values into its corporate culture.

We must point out that, although nowadays the speed with which information spreads and the ease with which we obtain data and information about a firm are undeniable, the difficulty of verifying their reliability is equally obvious, because of the spatial delocalisation of modern corporate systems. The result is a possible split between reality and appearance, in other words between what a firm really achieves and the image it wishes to convey, making it even more difficult to forge strong relations with its stakeholders.

The asymmetry of information between different players on the market implies that firms may occasionally communicate a social commitment to the outside world that is actually non-existent, or spread news about the social 'lack of commitment' of some competitors in order to discredit them, hoping to trigger a 'customer switch'.

In this situation, to return to Carroll's classification, the economic and legal responsibilities within corporate social responsibility will always prevail, while philanthropic and ethical responsibilities might become a contingent element, in other words present or absent as the case may be, used strategically to achieve the corporate goals.

The firm is therefore responsible for the social costs of its activities, for example pollution, and tries to take steps to reduce the socio-environmental impact of its operations (activities for which it is directly responsible). It tends to perform activities that apparently lie outside its economic function but which are, in fact, unavoidable in a strategic-competitive perspective of the evaluation of partial benefits and costs for the community (activities for which it is indirectly responsible). Similarly, from the perspective of the comparison of partial costs and benefits for given communities, a firm may, for example, assess the advisability of building schools in countries where it wishes to locate in order to maintain better relations with the community, organising training courses for its employees to perfect their professional skills, and arranging other activities to improve the internal working climate thus improving productivity. 


\section{Corporate Responsibility in Scarcity Economy}

The concept of corporate responsibility can be suitably analysed in relation to the competitive dynamics of the target market in which the firm operates ${ }^{37}$. Italy was in a state of 'scarcity economy' in the first half of the $20^{\text {th }}$ century, which concluded in the 1950s; however, the conditions persisted on some industries and we can still recognise situations similar to 'scarcity economy' today.

In a similar situation, the prevailing firm model is the one described by classic economic theory, in which output is a function of the manufacturing factors capital and work $\mathrm{Y}=\mathrm{f}(\mathrm{K}, \mathrm{L})$ where capital is the businessman's equity and work refers to workers other than the businessman and primarily without particular competencies or skills. Capital-intensive manufacturing methods, distinguished by the presence of capital invested in plant, coexist in the firm with labour-intensive methods, in which human labour prevails. The technology is simple enough to be incorporated into machinery whose cost, because it is relatively low, can be funded by individual businessmen ${ }^{38}$. Technological innovations are rare and their introduction is a direct consequence of specific motivations present in the offering firm, such as the need to change plant because of its technological obsolescence or the need to boost manufacturing capacity.

Production, which was initially artisan, subsequently became mass production, in which machines are often designed to perform functions in a sequence, and manufacturing cycles are repetitive and rigid; and finally, product characteristics are decided before manufacturing starts and cannot be changed during operations because of the rigidity of the manufacturing cycle ${ }^{39}$. The fact that the product cannot be modified during operations was not a problem for the firm; in fact, the demand for goods is clearly superior to the supply firms' capacity to meet it, so that everything manufactured is sold. Customers have elementary, known and stable needs. They request a product simply to perform its function, with the result that tangible components of supply prevail over intangible components ${ }^{40}$.

Manufacturing cycles are characterised by automation ${ }^{41}$; the processes are broken down into single operations that require man's intervention only for accessories duties, such as: moving semi-finished products from one plant to another, machine maintenance, and verification of the finished product. Employees therefore perform simple, repetitive functions that do not need particular preparation or professional skills, so they are often unqualified workers who are interchangeable.

Corporate communication is directed above all towards internal publics in order to motivate and involve them, facilitating their work, increasing productivity and fostering collaboration.

Briefly, we can identify an elementary firm model, in which the businessman has full control over his factory and production and does not have marketing problems, because all output will certainly be absorbed by demand. The competition space is the local environment, the firm is born and develops where the businessman lives and where the raw materials are available. Purchasers belong to the same local community as the factory, where goods are produced that are able to satisfy consumers' primary needs, and the entire local workforce has a job.

In this competitive situation, the firm's presence is essentially justified by its productive function. Its responsibilities consist in fabricating the goods requested by demand and in offering jobs to employees; purchasers do not make particular requests regarding the way goods are manufactured or their secondary 
characteristics, they only want to purchase a functioning product and to find it available in the point of sale. The firm therefore focuses its attention on its output and tends to increase capital spending on specialist machinery and to increase production volumes to recover its costs ${ }^{42}$. The scientific organisation of production, applied to this context, entails a level of systematic analysis of the plant mechanisms and a redefinition of its manufacturing processes. On one hand the firm looks for new, more efficient manufacturing solutions investing capital (K) in research, and on the other the lever on which the businessman may act is the workforce (L), selecting the employees and offering blue and white collar workers better living conditions ${ }^{43}$ that are more functional for manufacturing processes.

\section{Corporate Responsibility and Scarcity Economy: the Olivetti Case}

The Olivetti firm has played a key role in the Italian industrial panorama, not only because of its economic and technological performance, but also because of the particular attention it has paid to its employees and their problems. Analysis of this firm's development in the period 1908-1960 allows us to illustrate the concept of corporate responsibility in a competitive context of 'scarcity economy'.

\subsection{History of the Company ${ }^{44}$}

Founded in Ivrea on October 29, 1908 by Camillo Olivetti as 'Ing. C. Olivetti \& C.', the Olivetti firm was the first Italian manufacturer of typewriters. It initially had 20 employees, a plant of 500 square metres and a manufacturing capacity of 20 typewriters per week. The first model created was the M1, which was presented at the Turin Universal Exposition of 1911. In the 1920s a new machine was designed, the M20, and at the end of the decade, thanks to a drastic reorganisation of labour and the introduction of mass production, annual output reached 13,000 units. In the years that followed, the firm expanded, diversifying supply and extending its presence in Europe and the world, the number of branches in Italy increased, and the first foreign branch was created in Spain, followed by those in Belgium and Argentina. New manufacturing plants were opened in Italy and abroad. In the 1930s and 1940s the product range was extended to teleprinters, calculators, office furniture and equipment, numerical control machines and electric typewriters and calculators.

In 1932 Camillo's son, Adriano, took over the reins of the firm, becoming General Manager, and Chairman in 1938. He introduced a new cultural and innovative direction to the management, making Olivetti a unique model in Italian and European industrial history. Between 1934 and 1943, the year that Camillo Olivetti died, a sort of diarchy ${ }^{45}$ was introduced in the running of the firm, in which Adriano's tended to prevail; in the latter years of his life, the father dedicated his time exclusively to Officine Meccaniche Olivetti, where he was free to express himself as a designer and builder of machine tools. In the 1950s the country enjoyed a period of extraordinary economic growth, and under Adriano's guidance, Olivetti became the leader in the field of mechanical technology for office products. The cult products were the Lexikon 80, the Lettera 22 and the Divisumma Calculator. In the 1958, 50 years after its foundation, the firm had 24,000 employees, 10,000 of whom worked in the foreign branches, $60 \%$ of total 
production was exported and in 1959 it purchased Underwood, a large American typewriter manufacturer. Adriano Olivetti understood that electronics would become increasingly important in the field of calculators and office products, and he opened two research laboratories, a small one in New Canaan, Connecticut, and a laboratory specialising in electronics near to Pisa in 1955. The result of this capital spending was the Elea 9003, the first electronic calculator developed entirely in Italy, which was on the cutting edge because it was completely transistorised. Electronics offered new prospects for development. But when Adriano Olivetti died unexpectedly in 1960, a whole new series of problems emerged for the firm ${ }^{46}$.

The competitive condition of 'scarcity economy' was profoundly transformed due to fiercer competition on the markets. The manufacturing possibilities of firms increased thanks to the gradual updating of the systems, which made a large number of products available on the market. Firms came up against growing competition, no longer focused on a local space like the Canavese district, but internationally. The entrepreneurial decision to remain closed in this limited local space, convinced that the manufacturing function was still the focus around which entrepreneurial activities evolved and that it was still sufficient to overcome the new competitive tension, brought about the collapse of the firm. In the new competitive scenario, the marketing function became fundamental, because competitive conditions emerged, characterised by an instable balance between demand and supply $(D \cong S)$, linked to the availability of considerable quantities of products, which consequently imposed new relationships between the firm and consumers. It was now essential to analyse demand and break it down into homogeneous segments, in order to respond effectively and efficiently to the requests of each one. The strong competition between firms also made it necessary to study the clientele's needs, needs that evolved towards higher levels, being refined and differentiated, and it became indispensable for the firm to be able to design and manufacture products that met these new needs.

\subsection{Olivetti Strategic Orientation}

Adriano Olivetti constructed his activities around two fundamental concepts: the first was the conviction that in a backward society like Italy's, the 'factory ${ }^{47}$ represented the 'modern principle' of economic and social development; the second, that the factory's primary goal was to grow through the quantitative and qualitative development of its manufacturing factors, capital and labour. According to this vision, the firm had to create value not only to distribute to shareholders, but also to invest in self-financing of the activity itself, and therefore in better wages and salaries that could encourage a commitment to work, in social and welfare services for employees, continuous training and even shorter working hours for the same salary.

It is possible to identify five strategic directions followed by Adriano Olivetti ${ }^{48}$. First of all, the firm had to be a 'large firm' because that is the only way to respond to potential future economic opportunities. While he was Chairman, the firm grew from 200 employees in 1924 to 4000 in 1942 and 25,000 in 1961.

Secondly, Adriano Olivetti underlined the importance of technological innovation. Because he realised he was overseeing the complex transformation of a 
firm founded on semi-artisan systems into a large, more modern company, he introduced men with an outstanding scientific preparation into the industrial activities; his father's old collaborators, to whom the firm owed its foundation, development and many sacrifices, had to stand aside and make way for 'brilliant graduates in engineering, electromechanics and electronics ${ }^{49}$. Production was diversified, going from the simple differentiation of typewriters to the design of teleprinters and copiers.

Thirdly, the firm had to be international and compete on several markets in order to remain large and strong. In the 1930s and 1940s foreign branches were established in Belgium, Argentina, Spain, Brazil and France. When Adriano Olivetti died, the firm had manufacturing facilities in Italy (in the Canavese, in Turin, in Massa and in Pozzuoli), in Europe (Barcelona and Glasgow), in South America (Buenos Aires and Sao Paulo) and in the United States (Hartford).

Fourthly, Adriano Olivetti pursued his goal of spreading a strong corporate culture. As early as 1945 he maintained that 'it is important to give awareness of one's goals to labour ${ }^{50}$ and wondered: 'can industry set itself goals? Do they lie merely in the profit index? Isn't there something more attractive beyond the apparent rhythm, an ideal plot, a destination, or a vocation, even in the factory? ${ }^{51}$ His firm has always had the best engineers and the most skilled employees who, when they had cease working for Olivetti, took important roles in other firms. Many people were hired to fill specific firm functions, such as internal relations, communications or product design, and studies were undertaken that only later became academic subjects, such as business management and the sociology of labour.

Finally, Adriano Olivetti established a strong link between the 'factory' and the territory in which it was located; he created a range of services accessible to the whole population and not just to employees and their families, such as the Olivetti Social Relations Centre and the Olivetti Cultural Centres. He also founded I-Rur, the Institute for Urban and Rural renewal of the Canavese, which studied and executed municipal and inter-municipal programmes to improve social and economic conditions in the region, the standard of living and the cultural level of the population, to make a contribution to the full exploitation of the workforce and to promote, create and manage artisan, industrial and agricultural activities ${ }^{52}$. However, this strong link with the territory distracted Adriano Olivetti's attention from the changes that were affecting the external, now international, environment, and as a result he was unable to respond to them effectively.

\subsection{The Olivetti Welfare System}

The idea behind Olivetti's business conception, which was sustained by both Camillo and his son Adriano, was that the plant was not just a place whose purpose was to produce goods, but first and foremost a social environment where people lived together.

By tackling technical and financial problems as they presented themselves, Camillo and Adriano focused on the 'relations between the workers and the plant'. In his book Appunti per la storia di una fabbrica, Adriano wrote: 'in our early technical experience, when I was studying the problems of scientific organisation and timing, I knew that man and the machine were two forces hostile to each other that had to be reconciled. I was familiar with the terrible monotony and weight of 
actions repeated an infinitum in front of a drill or a press, and I knew it was necessary to relieve man from this degrading slavery. Initially I had to make do with wishing for the 'optimum' and not the 'maximum' of human energy, with perfecting the welfare tools and working conditions ${ }^{, 53}$.

The first social activities were organised with the Officina in 1909, when a Mutual Aid Fund was established among the workers, to provide healthcare and economic assistance in the event of an industrial accident or TB. The Mutual Aid Funds of the day were not very efficient: in order to be hospitalised, a worker had to send his documents to the main provincial town, and from there to Rome, and it could take about three months for them to be returned stamped for approval.

In 1919, anticipating legislation on the matter, a family allowance of 12 lire per dependent child was established for all employees. This family allowance continued to be paid over the years and in 1949 it evolved into a plan that supplemented the family allowance paid by INPS, the national welfare agency ${ }^{54}$.

In 1924, in response to the residential problems caused by the expanding workforce and poor housing conditions, Olivetti began to build housing for its employees ${ }^{55}$.

In 1932, Adriano took over the reins of the firm from his father, and introduced other novelties. He felt the weight of the firm's new, growing responsibilities, which put the plant at the centre of a new social community, whereas in the past it was only a complement to the rural economy ${ }^{56}$. Before 1936, Olivetti had offered personal assistance, almost in the form of charity, to the individual worker, whereas later it introduced a more structured welfare policy which Adriano himself defined as 'welfare system', based on the idea that the workers have rights, and that because they offered their labour to the firm it was right that they should have access to the welfare and other services set up in the firm, therefore on a 'quid pro quo' basis and not as charity ${ }^{57}$. Nursery schools, Summer holiday camps and factory services (canteens, automotive services and vehicle maintenance) were created for employees and their families. Technical and vocational schools were set up, like the Olivetti School, the Mechanics Training Centre and the Technical Industrial Institute, which offered scholarships to help the most able young people to become foremen and engineers; cultural services (Olivetti Cultural Centre, conferences, theatre performances, cinema, art exhibitions and concerts) and educational services (libraries, evening courses for employees) were organised. The Social Services Centre was set up with two goals: one was to promote the economic and social well-being of the corporate 'family', and the other, to avoid conflict and tension between management and workers in a moment of history when the workforce was growing rapidly. A policy to support motherhood and children was also promoted: in 1934 the first plant nursery school was built, with its own paediatric service, and in 1941 the Olivetti Female Workers regulations were adopted, providing more advantageous economic conditions than those envisaged by law for maternity leave, which secured the mother's job for nine months, practically at full salary.

The economic and structural growth of the firm meant that the housing question was always at the centre of attention; to solve it, after the war, new residential districts were built that respected modern planning philosophies, like Borgo Olivetti, Canton Vesco, Montemarino and Bellavista, loans and mortgages were available and employees could receive free technical and architectural advice. The intense building work also included the completion of the Ivrea plant, the 
construction of the Studies Centre, the project for the canteen, the school and the theatre, Ivrea hospital, the third bridge in Ivrea and the I-Rur plants ${ }^{58}$.

From 1948, the Institute for social services was managed by the Management Council, a body created to involve the workers directly in the welfare services present in the plant; one example was the Internal Solidarity Fund, which employees supported with a monthly contribution, and which provided aid in the event of illness or accidents, supplementing the national welfare and social security system.

One aspect of the hiring policy was to take on several members of the same family nucleus in order to increase their capacity for consumption and saving, and to prevent unbridled urbanisation of the territory. If we read the Personnel archives, we can see that $80 \%$ of the people hired by Olivetti between 1924 and 1960 continued to live in their native towns, thanks to an efficient, low cost transport system and easy term loans to restructure their homes. Even if the workforce increased considerably in those years, from 200 to 10,000 employees, as we mentioned earlier, the inhabitants of Ivrea only increased by five thousand and the population in the rest of the Canavese remained the same.

His policy of corporate responsibility towards the territory brought Adriano Olivetti into conflict with Confindustria, because he shortened working hours without lowering salaries, and with the Unions, because his ideas often anticipated theirs.

Adriano Olivetti understood before many others than the two levers at the firm's disposal to operate efficiently were the scientific organisation of manufacturing associated with the acquisition and use of specialist plant on one hand, and social management of the workforce so as to enhance relations of proximity between the firm and the environment on the other. The well-being of employees represented a valid condition to guarantee the continued success of the firm. For this reason, he undertook a number of activities for the social development of the firm such as the construction of Health Centres with convalescent homes and trained doctors for the employees and their families, to stop the spread of epidemics and debilitating diseases like TB, or the creation of workers' canteens to combat the nutrition problems of the day.

\section{Conclusions}

In scarcity economy, the firm operates in an environment that changes slowly and predictably, and this clearly defines the relationship between the business and the environment. The firm has to perform a manufacturing role in response to the elementary and stable needs of demand, and the prosperity and well-being of the local community in which it is located generate the conditions for its development and its survival in the long term. The workforce, suppliers, purchasers, manufacturing processes and the capital that is often tied up in facilities, constitute the 'firm system'; the players on the market are well-known and defined stably, and the territorial proximity makes it fairly simple for the firm to establish advantageous relations with them to perform its activities. The boundaries of the market are easily identified and technological innovations are rare and predictable, so that in the short term no sudden environmental changes occur and the firm can concentrate on a more internal dimension because, in this context, profit can only 
be maximised by improving internal efficiency through the creation of economies of scale.

Corporate responsibility, seen as a firm's commitment to answer for its activities and for the economic and social effects they may have, is therefore valued inside a local territory defined by the procurement market on one hand and by the outlet market on the other. There is a relationship of control and collaboration between the businessman and the local community. This link makes the concept of social responsibility implicit in firm's activities because meeting the elementary needs of society through the manufacture of goods makes it possible for the economic and social functions of the business to coincide. Therefore, although it is possible in every competitive situation to attribute economic, legal, ethical and philanthropic aspects to the corporate responsibility in scarcity economy, the emphasis is on economic responsibility because of the reduced capacity of supply to guarantee the required quantity.

We must however underline that whatever the competitive situation in which the firm develops, whether one of 'scarcity' or of 'over-supply', in order to have success, it is not sufficient for a firm to be capable from a technical-manufacturing perspective, in other words to efficiently perform its economic function, but it is also very important for it to be accepted by society.

The attention to the social implications of a firm's activity was also valued and considered in the first half of the last century, a period characterised by a scarcity of products. In those days, the proprietor and manager of a firm was involved directly in the organisational, administrative and management aspects of the corporate structure, and he was personally acquainted with suppliers and employees, because all the social interlocutors were present in the same local space. As a result, very often a firm's social commitment was an expression of the businessman's own morality; in the case in question, for example, Adriano Olivetti's attention to the social problems of his age was responsible for the Olivetti firm's social policies in favour of its employees and their families.

Adriano Olivetti was perceived by some of his contemporaries as a 'troublesome' businessman and later as an 'enlightened' businessman, but in fact he simply had a strong sense of responsibility towards his employees, their families and in general the territory of Ivrea, and he succeeded in creating an 'Olivetti-system' through the creation of favourable attitudes and consensus for the firm, improving the quality of the life of his fellow citizens, developing shared value systems; generating a strong sense of belonging to his firm, fostering the motivation of the individual and constructing a strong brand with a very positive image.

\section{Bibliography}

AA.VV., Speciale per Adriano Olivetti, l'uomo che visse il futuro, La Sentinella del Canavese, 2001.

Airoldi G., Brunetti G., Coda V., Economia Aziendale, Il Mulino, Bologna, 1994.

Baccarani C., Testa F., Ugolini M., Le scelte competitive nell'evoluzione delle attese sociali, Sinergie, n. 31, 1993.

Berta G., Le idee al potere. Adriano Olivetti tra la fabbrica e la Comunità, Edizioni di Comunità, Ivrea, 1980.

Bowen H.R., Social Responsibility of the Businessman, Harper \& Row, New York, 1953. 
Brondoni S.M., Brand Policy and Brand Equity, Symphonya. Emerging Issues in Management (symphonya.unimib.it), n.1, 2000-2001.

http://dx.doi.org/10.4468/2001.1.02brondoni

Brondoni S.M., Comunicazione, risorse invisibili e strategia competitiva d'impresa, Sinergie, n. 43/44, 1997.

Brondoni S.M., Etica e comunicazioni interne d'azienda, in AA.VV., Istituzioni d'economia d'azienda. Scritti in onore di Carlo Masini, Tomo Primo, Egea, Milan, 1993.

Cafferata R., Sistemi ambiente e innovazione. Come si integrano la continuità e il mutamento nell'impresa, Giappichelli, Turin, 1995.

Carroll A.B., A Three Dimensional Conceptual Model of Corporate Performance, Academy of Management Review, Vol. 14, 1979. http://dx.doi.org/10.5465/AMR.1979.4498296

Carroll A. B., Business and Society. Ethics and Stakeholder Management, $2^{\text {nd }}$ Edition, SouthWestern Publishing Co., 1993.

Caselli C., Benevolo c., Produzione di valore e formula di imprenditorialità sociale: il caso del Banco Alimentare, Sinergie, n. 53, 2000.

Caselli L., Etica dell'impresa e nell'impresa, Sinergie, n. 45, 1998.

Coda V., Etica e impresa: il valore dello sviluppo, in Corno F. (ed), Etica e impresa: scelte economiche e crescita dell'uomo, Cedam, Padua, 1989.

Corniani M., Sistema informativo aziendale e dinamiche competitive, Giappichelli, Turin, 2000.

Cyert R.M., March J.G., A Behavioural Theory of The Firm, Blackwell, Cambridge, 1992.

Davis K., Can Business Afford to Ignore Social Responsibilities?, California Management Review, Spring, 1960

Davis K., Understanding the Social Responsibility Puzzle, Business Horizons, Vol. 10, 1967. http://dx.doi.org/10.1016/0007-6813(67)90007-9

Di Bernardo B., Rullani E., Il management e le macchine, Il Mulino, Bologna, 1990.

Di Toro P., L'etica nella gestione d'impresa, Cedam, Padua, 1993.

Drucker P., The New Meaning of Corporate Social Responsibility, California Management Review, Vol. 26, 1984.

Epstein E.M., Societal Managerial and Legal Perspectives on Corporate Social Responsibility, California Management Review, Vol. 29, 1979.

Frederick W., The Growing Concern over Business Responsibility, California Management Review, Summer, 1960.

Frederick W., Toward CSR3: Why Ethical Analysis is Indispensable and Unavoidable in Corporate Affairs, California Management Review, Vol. 28, 1986.

Freeman E.R., Strategic Management. A Stakeholder Approach, Pitman, Boston, 1984.

Friedman M., Capitalism and Freedom, University of Chicago Press, Chicago, 1962.

Gallinaro S., La produzione nell'economia dell'impresa industriale: da 'funzione' a 'scuola', Giappichelli, Turin, 1996.

Gatti M., Barile S., Riflessioni sull'etica nell'impresa secondo l'approccio sistemico, Esperienze di Impresa, Speciale 1, 2003.

Gnecchi F., La comunicazione istituzionale dell'ente locale territoriale, Giappichelli, Turin, 1999.

Golinelli G. M., Gatti M., The Firm as a Viable System, Symphonya. Emerging Issues in Management (symphonya.unimib.it), n. 2, 2000-2001.

http://dx.doi.org/10.4468/2001.2.04golinelli.gatti

Golinelli G. M., L’approccio sistemico al governo dell'impresa. L’impresa sistema vitale,Vol.1, Cedam, Padua, 2000.

Golinelli G. M., Impatto ambientale, responsabilità sociale, strategia di impresa, implicazioni di carattere finanziario, in AA.VV., Scritti in onore di Luigi Guatri, Vol. 1, Ed. Bocconi, Milan, 1988.

Gummesson E., Total Relationship Marketing, Butterworth-Heinemann/The Chartere d'Institute of Marketing, Oxford, 1999. 
Gustavsson B., The Human Values of Swedish Management, Journal of Human Values, vol.1, n. 2, 1995.

Johnson H., Business in Contemporary Society: Framework and Issues, Belmont, CA, Wadsworth, 1971.

Keynes J.M, Teoria generale dell' occupazione, dell'interesse e della moneta e altri scritti, Utet, Turin, 2001.

Lago U., L'etica nella gestione d'impresa, Economia e Management, n. 3, 1995.

Lambin J.J., Brondoni S.M., Ouverture de 'Market-Driven Management, Symphonya. Emerging Issues in Management (symphonya.unimib.it), n. 2, 2000-2001. http://dx.doi.org/10.4468/2001.2.01ouverture

Lambin J.J., Market-Driven Management, MacMillan, London, 2000.

Maggia G., Adriano Olivetti, in Speciale per Adriano Olivetti, l'uomo che visse il futuro, La Sentinella del Canavese, 2001.

Manne H.H., Wallich H.C., The Modern Corporation and Social Responsibility, Washington, 1972.

Marques E., Le bilan social, Dalloz, Paris, 1978.

Masini C., Il dinamismo moderno e l'osservazione quantitativa d'azienda, Giuffrè, Milan, 1964.

Masini C., La struttura dell'impresa, Giuffrè, Milan, 1964.

Masini C., Lavoro e risparmio, Utet, Turin, 1979.

Matacena A., Impresa e ambiente: il bilancio sociale, Clueb, Bologna, 1984.

McGuire J., Business and Society, McGraw Hill, New York, 1963.

Molteni M., L’impresa tra competitività e responsabilità, Impresa e Stato, Vol. 65, 2003.

Nibale G., L'etica aziendale, l'economicità aziendale e l'economicità sociale, Finanza, Marketing $e$ Produzione, n. 4, 1995.

Olivetti A., Appunti per la Storia di una fabbrica, in Musatti R, Bigiaretti L., Soavi G., Olivetti 1908-1958, Ing. Olivetti \& Company S.p.A., Ivrea, 1958.

Olivetti A., Corrispondenza per gli Stati Uniti, Edizioni di Comunità, 1953.

Olivetti A., Discorsi ai lavoratori, in Città dell'uomo, Edizioni di Comunità 1960.

Onida P., Il bilancio di esercizio nelle imprese, Giuffrè, Milan, 1951.

Onida, P. L'azienda. Fondamentali problemi della sua efficienza, Giuffrè, Milan, 1955.

Onida P., Economia d'Azienda, Utet, Turin, 1960.

Pampaloni G., Adriano Olivetti: un'idea di democrazia, Edizioni di Comunità, Varese, 1980.

Piore M.J., Sabel C., Le due vie dello sviluppo industriale. Produzione di massa e produzione flessibile, ISEDI, Turin, 1987.

Porter M., Kramer M.R., The Competitive Advantage of Corporate Philanthropy, Harvard Business Review, December, 2002.

Ragazzino G., Staglianò I., Il conto del tempo. Operai lotte ristrutturazioni nuove tecnologie profitti e grande fabbrica. Fiat, Olivetti e produttività, Ed. Rosenberg \& Sellier, Turin, 1980.

Rispoli M., Ruolo sociale e responsabilità sociale delle imprese, Sinergie, n. 31, 1993.

Ronchetti S., Ricerche per la biografia in Speciale per Adriano Olivetti, l'uomo che visse il futuro, in La Sentinella del Canavese, 2001.

Rusconi G., Etica e impresa. Un'analisi economico-aziendale, Clueb, Bologna, 1997.

Sacconi L., Etica e Responsabilità sociale di impresa: cosa accomuna e cosa distingue l'impresa sociale dalle altre forme di impresa?, Università Cattaneo LIUC, Castellanza, 2002.

Sacconi L., L'etica degli affari. Individui, imprese e mercati nella prospettiva di un'etica razionale, Il Saggiatore, Milan, 1991.

Sapelli G., Responsabilità d'Impresa, Guerini Editore, Milan, 1996.

Saraceno P., La produzione industriale, Libreria Universitaria Editrice, Venice, 1970

Sciarelli S., Economia e gestione dell'impresa, Seconda Edizione, Cedam, Padua, 2001. 
Sciarelli S., La produzione del valore allargato quale obiettivo dell'etica nell'impresa, Finanza, Marketing e Produzione, December, 2002.

Semplici S., Un'azienda e un'utopia. Adriano Olivetti 1945-1960, Società Editrice Il Mulino, Bologna, 2001.

Sethi P., Dimensions of Corporate Social Performance: an Analytical Framework, California Management Review, Vol. 17, 1975.

Tarquinio L., Aspetti evolutivi del rapporto impresa ambiente fisico-naturale, Rivista Italiana di Ragioneria e di Economia Aziendale, Vol. 7/8, 1997.

Terzani S., Responsabilità sociale dell'azienda, Rivista Italiana di Ragioneria ed Economia Aziendale, July-August, 1984.

Varian H. R., Microeconomia, Cafoscarina, Venice, 1988.

Vermiglio F., La responsabilità sociale dell'impresa, Industria Poligrafica della Sicilia, Messina, 1983.

Zamagni S., La responsabilità sociale dell'impresa: presupposti etici e ragioni economiche in L'impresa giusta. Responsabilità e rendicontazione sociale nella cooperazione, Il Ponte Editore, Perugia, 2003.

Zappa G., Le produzioni nell'economia delle imprese. Tomo primo, Giuffrè, Milan, 1956.

\section{Notes}

${ }^{1}$ In this regard, it may be useful to trace the etymology of the word 'responsibility' which derives from the Latin respondeo, which in turn derives from spondeo: to give a legal guarantee, to personally vouch for someone, up to the modern day, when the term has the significance of answering personally for an action. In other words, we can state that the word 'responsibility' expresses the existence of a number of obligations on the part of the person who has it.

${ }^{2}$ Cf. G. Golinelli, M. Gatti, The Firm as a Viable System, Symphonya. Emerging Issues in Management (symphonya.unimib.it), n. 2, 2000-2001, p. 71: 'The external context .... has been seen as an indistinct sum of entities. These entities, from the perspective of the governance organ, emerge as systems that receive an input of resources and generate an output of goods and services. Now for the governance organ, the problem of analysing the context becomes that of identifying the systemic entities present as possible significant systems or, more simply, influential for the evolutionary dynamics of the vital corporate system.'

${ }^{3}$ Cf. G. Golinelli, L'approccio sistemico al governo dell'impresa. L'impresa sistema vitale, Vol. 1, Cedam, Padua, 2000, p. 63.

${ }^{4}$ Cf. S. Sciarelli, Economia e gestione dell'impresa, Second Edition, Cedam, Padua, 2001, p. 31: 'The constraints ..... can depend on laws or administrative decrees, on the prevailing cultural model, the composition and mobility of social classes, the way the economy is controlled and the degree of well-being of the population. Each sphere generates conditioning elements that eventually limit the businessman's space for manoeuvre ....'

${ }^{5}$ See G. Zappa, Le produzioni nell'economia delle imprese. Tomo Primo, Giuffrè, Milan, 1956, p. 312.

${ }^{6}$ See P. Onida, Il bilancio di esercizio nelle imprese, Giuffrè, Milan, 1951, p. 33.

${ }^{7}$ See P. Onida, L'azienda. Fondamentali problemi della sua efficienza, Giuffrè, Milan, 1955, pp. 12.

${ }^{8}$ Cf. P. Saraceno, La produzione industriale, Libreria Universitaria Editrice, Venice, 1970.

${ }^{9}$ Cf. C. Masini, Il dinamismo moderno e l'osservazione quantitativa d'azienda, Giuffrè, Milan, 1964.

${ }^{10}$ See C. Masini, La struttura dell'impresa, Giuffrè, Milan, 1964, p. 15.

${ }^{11}$ The concept of stakeholder was considered for the first time in 1963 by the Stanford Research Institute and this category initially only included parties with a direct interest in the life of the firm: shareholders, employees, customers and suppliers. However, over the years the concept has been expanded with the definition given by Freeman, according to whom a stakeholder is any well identifiable individual who can influence or be influenced by the organisation's activities in terms of 
products, policies and working processes. By this definition, public interest groups, protest movements, local communities, government agencies, business associations, competitors, trade unions and the media can all be considered stakeholders. Cf. E. Freeman, Strategic Management. A Stakeholder Approach, Pitman, Boston, 1984; A. C. Carroll, Business \& Society. Ethics and Stakeholder Management, South Western, Cincinnati, 1993; S. Sciarelli, Economia e gestione dell'impresa, Second Edition, Cedam, Padua, 2001.

12 The corporate economy has gradually extended the ethical aspects of corporate management, developing a field of study in business ethics which investigates the reasons why an economic institution like a firm can pursue ethical behaviour. Although the evolution of ethical thought is not the subject of this study, it is useful to remember the dichotomy between utilitarianism and deontology which is essential when discussing the ethics of economic activities. In general, the utilitarian conception states that behaviour is ethical if it brings positive results, and the individual who pursues his own interests, in an unintentional way will also pursue the interests of the firm; the deontological conception on the other hand, maintains that there are absolute principles and values that must be respected as such, independently of any consequences that they may have for the individual. If we refer these views to corporate economics we can state that according to utilitarian thought, the firm will adopt ethical behaviour not out of pure philanthropy, but because it is convenient from an economic-corporate perspective (analysis of costs met/expected benefits). According to the deontological criterion, on the other hand, the firm must respect absolute ethical standards even if this can have negative repercussions for its performance. The utilitarian conception seems closer to modern business. Cf. G. Rusconi, Etica e impresa. Un'analisi economico-aziendale, Clueb, Bologna, 1997. See also P. Di Toro, L'etica nella gestione d'impresa, Cedam, Padua, 1993.

${ }^{13}$ See H. R. Bowen, Social Responsibility of the Businessman, Harper \& Row, New York, 1953, p. 11: 'It refers to the obligations of businessman to pursue those policies, to make those decisions, or to follow those lines of action which are desirable in terms of the objectives and values of our society'.

${ }^{14}$ This debate was probably influenced by Keynes' economic theory. Until the 1930s, the classical economic viewpoint dominated, according to which a market left to its own devices would find a balance thanks to the simple effect of the economic forces of demand and supply; but the consumer crisis of 1929 revealed the inadequacy of this model. The entrance of public capital into the economic system is an element that characterises the so-called condition of a 'welfare state', in which State intervention in the economy is designed to maintain a specific state of competition in a context substantially defined by precise political, economic and legislative (fiscal, currency, standards, financial) boundaries in which particular protectionist policies have been put in place to discourage foreign operators from entering the system. We can even hypothesize that this is the moment when elementary corporate goals of profit maximisation, typical of classical economics, are combined with new social goals within the concept of business. Cf. J.M. Keynes, Teoria generale dell' occupazione, dell'interesse e della moneta e altri scritti, Utet, Turin, 2001.

${ }^{15}$ See M. Friedman, Capitalism and Freedom, University of Chicago Press, Chicago, 1962, p. 60: '..there is one and only one social responsibility of business: to use its resources and engage in activities designed to increase its profit so long as it stays within the rules of the game, which is to say, engages in open and free competition without deception or fraud.' This theory, which is also known as the stockholder theory, states that assessments outside the pure economic sphere of business cannot be taken into consideration during the firm's decision-making process because they only represent a threat in relation to profit maximisation.

${ }^{16}$ See K. Davis, Can Business Afford to Ignore Social Responsibilities?, California Management Review, Spring, 1960, p. 70: ‘....businessmen's decisions and actions taken for reasons at least partially beyond the firm's direct economic or technical interest'.

${ }^{17}$ See W. Frederick, The Growing Concern over Business Responsibility, California Management Review, Summer, 1960, p. 60: 'Social responsibility in the final analysis implies a public posture toward society's economic and human resources and those resources are utilized for broad social ends and not simply for the narrowly circumscribed interests of private persons and firms.'

${ }^{18}$ See J. McGuire, Business and Society, McGraw Hill, New York, 1963, p. 144: 'The idea of social responsibility supposes that the corporation has not only economic and legal obligations, but also certain responsibilities to society which extend beyond these obligations.' 
${ }^{19}$ Cf. H. Johnson, Business in Contemporary Society: Framework and Issues, Belmont, CA, Wadsworth, 1971.

${ }^{20}$ Cf. H. H. Manne, H. C. Wallich, The Modern Corporation and Social Responsibility, Washington, 1972.

${ }^{21}$ Cf. K. Davis, Understanding the Social Responsibility Puzzle, Business Horizons, Vol. 10, 1967.

22 Cf. P. Sethi, Dimensions of Corporate Social Performance: an Analytical Framework, California Management Review, Vol. 17, 1975.

23 Cf. E. M. Epstein, Societal Managerial and Legal Perspectives on Corporate Social Responsibility, California Management Review, Vol. 29, 1979.

24 See A. B. Carroll, A Three Dimensional Conceptual Model of Corporate Performance, Academy of Management Review, Vol. 14, 1979, p. 500: 'The social responsibility of business encompasses the economic, legal, ethical and discretionary expectations that society has of organizations at a given point in time.'

${ }^{25}$ Cf. P. Drucker, The New Meaning of Corporate Social Responsibility, California Management Review, Vol. 26, 1984.

${ }^{26}$ Cf. W. Frederick, Toward CSR3: why ethical analysis is indispensable and unavoidable in corporate affairs, California Management Review, Vol. 28, 1986.

${ }^{27}$ Cf. E. Marques, Le bilan social, Dalloz, Paris, 1978.

${ }^{28}$ Cf. G. Zappa, Le produzioni nell'economia delle imprese, Istituto Editoriale Scientifico, Milan, 1956; P. Onida, Economia d'Azienda, Utet, Turin, 1960; C. Masini, Lavoro e Risparmio, Utet, Turin, 1979; S. Terzani, Responsabilità sociale dell'azienda, Rivista Italiana di Ragioneria ed Economia Aziendale, July-August, 1984; A. Matacena, Impresa e ambiente: il bilancio sociale, Clueb, Bologna, 1984; V. Coda, Etica e impresa: il valore dello sviluppo, in Corno F. (edited by), Etica e impresa: scelte economiche e crescita dell'uomo, Cedam, Padua, 1989; L. Sacconi, L'etica degli affari. Individui, imprese e mercati nella prospettiva di un'etica razionale, Il Saggiatore, Milan, 1991; AA.VV., 'Istituzioni d'economia d'azienda. Scritti in onore di Carlo Masini', Tomo Primo, Egea, Milan, 1993; P. Di Toro, L'etica nella gestione d'impresa, Cedam, Padua, 1993; G. Nibale, L'etica aziendale, l'economicità aziendale e l'economicità sociale, Finanza, Marketing $e$ Produzione, no. 4, 1995; U. Lago, L'etica nella gestione d'impresa, Economia e Management, no. 3, 1995; G. Sapelli, Responsabilità d'Impresa, Guerini Editore, Milan, 1996; G. Rusconi, Etica e impresa. Un'analisi economico-aziendale, Clueb, Bologna, 1997; L. Caselli, Etica dell'impresa e nell'impresa, Sinergie, no. 45, 1998; C. Caselli, C. Benevolo, Produzione di valore e formula di imprenditorialità sociale: il caso del Banco Alimentare, Sinergie, no. 53, 2000, L. Sacconi, Etica e Responsabilità sociale di impresa: cosa accomuna e cosa distingue l'impresa sociale dalle altre forme di impresa?, Università Cattaneo LIUC, Castellanza, 2002; S. Sciarelli, La produzione del valore allargato quale obiettivo dell'etica nell'impresa, in Finanza, marketing e produzione, December, 2002, M. Molteni, L'impresa tra competitività e responsabilità, in Impresa e Stato, Vol. 65, 2003, S. Zamagni, La responsabilità sociale dell'impresa: presupposti etici e ragioni economiche. in L'impresa giusta. Responsabilità e rendicontazione sociale nella cooperazione, Il Ponte Editore, Perugia, 2003.

${ }^{29}$ Cf. S. Sciarelli, Economia e Gestione dell'Impresa, Second Edition, Cedam, 2001. For further details we refer you to the Behaviourist Theory which considers the firm as composed of a sum of individuals (workers, suppliers, shareholders, customers, etc.) who table a process of negotiation about the targets to reach. Cf. R.M. Cyert \& J.G. March, A Behavioral Theory of The Firm, Blackwell, Cambridge, 1992.

${ }^{30}$ See S. Sciarelli, Economia e Gestione dell'Impresa, Second Edition, Cedam, Padua, 2001, p. 5.

${ }^{31}$ See G. Airoldi, G. Brunetti, V. Coda, Economia Aziendale, Il Mulino, Bologna, 1994, p. 16.

32 Cf. S. M. Brondoni, Brand Policy and Brand Equity, Symphonya. Emerging Issues in Management (symphonya.unimib.it), n. 1, 2000-2001. If we compare demand and supply, we can distinguish between three extreme situations: 'scarcity economy', characterised by demand that exceeds supply $(\mathrm{D}>\mathrm{S})$, conditions of 'dynamic balance between demand and supply' $(\mathrm{D} \cong \mathrm{S})$, and 'over-supply', where supply is decidedly superior to demand (D < S). 
${ }^{33}$ Cf. F. Vermiglio, La responsabilità sociale dell'impresa, Industria Poligrafica della Sicilia, Messina, 1983.

${ }^{34}$ See L. Tarquinio, Aspetti evolutivi del rapporto impresa ambiente fisico-naturale, Rivista Italiana di Ragioneria e di Economia Aziendale, Vol. 7/8, 1997, p. 390.

${ }^{35}$ An externality arises when the manufacture or consumption of a subject positively or negatively influences another party's well-being, and the latte does not receive any compensation (in the case of a negative impact) or pay a price (in the case of a positive impact) equal to the cost or benefit met/received. Cf. H. R. Varian, Microeconomia, Cafoscarina, Venice, 1988.

${ }^{36}$ Cf. S. M. Brondoni, Comunicazione, risorse invisibili e strategia competitiva d'impresa, in Sinergie, n. 43/44, 1997.

${ }^{37}$ Cf. S. M. Brondoni, Brand Policy and Brand Equity, Brand Equity, Symphonya. Emerging Issues in Management, (symphonya.unimib.it), n. 1, 2000-2001.

${ }^{38}$ See B. Di Bernardo, E. Rullani, Il management e le macchine, Il Mulino, Bologna, 1990, p. 188.

${ }^{39}$ Ibid.

${ }^{40}$ Cf. S. M. Brondoni, Comunicazione, risorse invisibili e strategia competitiva d'impresa, Sinergie no. 43/44, 1997.

${ }^{41}$ Cf. M. J. Piore, C. Sabel, Le due vie dello sviluppo industriale. Produzione di massa e produzione flessibile, ISEDI, Turin, 1987.

${ }^{42}$ Cf. S. Gallinaro, La produzione nell'economia dell'impresa industriale: da 'funzione' a 'scuola', Giappichelli, Turin, 1996.

${ }^{43}$ To describe this behaviour adopted by firms, scholars of economic history speak of 'paternalism', seen as a view of the worker's role in the firm; even though, in the case of Adriano Olivetti, Giuseppe Berta considers it more appropriate to talk of dirigisme rather than paternalism. See G. Berta, Le idee al potere. Adriano Olivetti tra la fabbrica e la Comunità, Edizioni di Comunità, Ivrea, 1980, pp. 120-124.

${ }^{44}$ The information collected is taken from the site www.storiaolivetti.telecomitalia.it, AA.VV., Speciale per Adriano Olivetti, l'uomo che visse il futuro, in La Sentinella del Canavese, 2001; G. Ragazzino, I. Staglianò, 1980, Il conto del tempo. Operai lotte ristrutturazioni nuove tecnologie profitti e grande fabbrica. Fiat, Olivetti e produttività, Ed. Rosenberg \& Sellier, Turin; G. Berta, Le idee al potere. Adriano Olivetti tra la fabbrica e la Comunità, Edizioni di Comunità, Ivrea, 1980; S. Semplici, 2001, Un'azienda e un'utopia. Adriano Olivetti 1945-1960, Società Editrice Il Mulino, Bologna.

${ }^{45}$ Cf. G. Maggia, Adriano Olivetti, in Speciale per Adriano Olivetti, l'uomo che visse il futuro, in La Sentinella del Canavese, 2001.

${ }^{46}$ The purchase of Underwood, the investment necessary to finance the Electrical Division and a domestic market not yet ready to absorb the supply of computers, generated a difficult economic situation. The Olivetti family had maintained its strong control over the firm, even after it was listed on the Stock Exchange in 1960, but was forced to sell both a part of its shareholding and the Electronic Division in 19674. Initially it held onto $25 \%$ of the shares, selling the remainder to General Electric, but in 1968 it disposed of those shares too. The disposal of the Electrical Division clearly conditioned Olivetti's development and technological evolution, obliging manufacturing and design to concentrate on small machines and distributed IT. The 1970s marked an important turnaround for Olivetti which focused on electronics, acquiring very costly new technologies that worsened the financial situation. In 1978, Carlo De Benedetti invested in the company, taking responsibility for operations and cleaning up its finances with successive recapitalisations. In the 1980s, growth gathered pace thanks to acquisitions, agreements and international alliances, including the agreement signed with AT\&T. The company's commitment to IT led to the launch of numerous families of systems and of new activities in the field of IT services. In the 1990s, having understood the strong potential for development of telecommunications, Olivetti and other investors created the Omnitel mobile telephone company. In 1995, Infostrada was founded in the field of fixed telephony and, the following year, at a particularly difficult moment for the company, then led by Roberto Colaninno, it began a process of drastic transformation; new alliances were forged with the Mannesmann company, operations in the field of personal computers were sold off and the company focused on a specific area (products for the office, specialist systems, IT services). In 
February 1999, Olivetti and its subsidiary Tecnost announced their intention to launch a leveraged buy-out and swap (LBO) on all the ordinary shares of Telecom Italia. The operation was concluded in June with the acquisition of over $52 \%$ of the share capital of Telecom Italia, and at the same time, Olivetti sold its investment in Omnitel and Infostrada to Mannesmann, as requested by antitrust legislation. The majority stake was then in the hands of Bell S.A., a company registered in Luxembourg by Italian financiers and industrialists. However, the level of indebtedness generated by the LBO prompted the sale of the majority stake to Pirelli and Benetton. The Olimpia company was established, owned by Pirelli, Edizione Holding, Intesa-BCI and Unicredito, which became the major shareholder in Olivetti with a share of approximately 29\%. Marco Tronchetti Provera and Carlo Buora were appointed as the new Managing Directors and a new period in Olivetti history began, focusing primarily on telecommunications through the Telecom Italia companies. Managerial coordination with Telecom Italia itself was also stepped up. Following the merger, Olivetti changed its corporate purpose, adopting that of Telecom Italia, as well as the company name.

${ }^{47}$ In his speeches, Adriano Olivetti always talked of the 'factory' because he identified the firm with the factory, which at the time was the most obvious aspect of his entrepreneurial activities, but today it would be more correct to talk about the business.

${ }^{48}$ Cf. G. Maggia, Adriano Olivetti, in Speciale per Adriano Olivetti, l'uomo che visse il futuro, in La Sentinella del Canavese, 2001.

${ }^{49}$ See A. Olivetti, Appunti per la Storia di una fabbrica, 1958, p. 9, in Musatti R, Bigiaretti L., Soavi G., Olivetti 1908-1958, Ing. Olivetti \& Company S.p.A., Ivrea, 1958.

${ }^{50}$ See A. Olivetti, Discorsi ai lavoratori, in Città dell'uomo, 1960, p. 163.

${ }^{51}$ Cf. A. Olivetti, Appunti per la Storia di una fabbrica, in Musatti R., Bigiaretti L., Soavi G., Olivetti 1908-1958, Ing. Olivetti \& Company S.p.A., Ivrea, 1958. We also refer you to Olivetti, Adriano, Corrispondenza per gli Stati Uniti, Edizioni di Comunità, 1953: 'Indiscriminate use of masses of unskilled workers, with a low intellectual and physical level, is a serious obstacle to orderly economic development.'

${ }^{52}$ For further analysis we refer you to the Statue of the Institute for Urban and Rural Renewal in the Canavese.

${ }^{53}$ Cf. A. Olivetti, Appunti per la Storia di una fabbrica, in Musatti R., Bigiaretti L., Soavi G., Olivetti 1908-1958, Ing. Olivetti \& Company S.p.A., Ivrea, 1958.

${ }^{54}$ Cf. AA.VV., Speciale per Adriano Olivetti, l'uomo che visse il futuro, La Sentinella del Canavese, 2001.

55 Ibid.

${ }^{56} \mathrm{Cf}$. Ronchetti S., Ricerche per la biografia in Speciale per Adriano Olivetti, l'uomo che visse il futuro, in La Sentinella del Canavese, 2001.

${ }^{57}$ In the introduction to Volume Servizi e Assistenza sociale di fabbrica, Adriano Olivetti wrote: 'Social Services provides solidarity. Each of the firm's employees contributes with his work to the life of the firm itself and therefore to that of the organisms set up within it, and he may therefore access the Welfare Institute and ask for the relative benefits, without this taking the form of a personal favour to him.'

${ }^{58}$ Cf. G. Pampaloni, Adriano Olivetti: un'idea di democrazia, Edizioni di Comunità, Varese, 1980, p. 84: 'Basically, what really drove Olivetti was not wanting to create individual pieces of architecture, but to state the need and verify the possibilities of a qualitative social architecture, which was private initially but was naturally projected into a public dimension.' 